\title{
Николаева Н.Т. \\ Роль учебной дисциплины «Деловой иностранный язык» в формировании межкультурной компетенции магистрантов
}

ФГБОУ ВО «Оренбургский государственный педагогический университет»

(Россия, Оренбург)

doi: 10.18411/trnio-11-2021-168

\section{Аннотация}

В статье рассматриваются особенности формирования межкультурной компетенции магистрантов в рамках учебного предмета «Деловой иностранный язык». Подробно описываются и анализируются условия обучения магистрантов дисциплине «Деловой иностранный язык», направленные не только на изучение основных правил написания делового письма и организацию делового общения на иностранном языке, но и на развитие межкультурной компетенции магистранта.

Ключевые слова: магистрант, межкультурная компетенция, деловой иностранный язык, деловое письмо, деловое общение.

\section{Abstract}

The article pays special attention to the peculiarities of the formation of intercultural competence of undergraduates in the framework of the academic subject "Business Foreign Language". We describe and analyze in detail conditions of teaching master students in the discipline "Business Foreign Language". That aims not only at studying the basic rules of writing a business letter and organizing business communication in a foreign language, but also at developing the intercultural competence of a master student.

Keywords: undergraduate, intercultural competence, business foreign language, business writing, business communication.

Модернизация высшего образования в России в настоящее время предполагает формирование у магистрантов опыта использования знаний, умений и навыков в сфере деловой коммуникации в их дальнейшей профессиональной деятельности. Ожидаемые результаты образования на основе данного подхода описаны в качестве компетенций, которые сформулированы в соответствии со стандартами структуры общекультурных и профессиональных компетенций. Профильные компетенции в ФГОС ВО 3 поколения определяются исключительно вузом [1]. Но, в то же время, содержание и структура межкультурной компетенции и требования к её уровню для разных профилей подготовки установлены, и определена её роль в профессиональной компетентности магистрантов. Чтобы её сформировать, в образовательный процесс включена дисциплина «Деловой иностранный язык».

Исходя из опыта преподавания дисциплины «Деловой иностранный язык» мы считаем, что необходимым условием формирования межкультурной компетенции магистранта является использование на занятиях материалов, содержащих социокультурный и культуроведческий аспект изучаемого языка и способствующих обучению магистрантов правилам составления деловой корреспонденции на иностранном языке [2].

Например, мы предлагаем магистрантам выполнить следующие задания:

Task. Match the parts of the letter (1-9) with their names (A-I):

1. Rebecca Wilson

International Services Inc

3467 Clifford Road

Houston, TX 79143

2. Yours faithfully,

3. R. Wilson 
Manager

4. The team of our managers has seen your advertisement in the Business Weekly Journal, and will certainly appreciate if you send us more detailed description of your new VIAR cameras. We would also be grateful to know the discounts if you provide any.

5. Dear Sirs,

6. We are looking forward to hearing from you soon.

7. New Reality Inc

9876, Ample Street

Los Angeles, LA 46943

8. Our company International Services Inc specializes in distributing VIAR cameras in Russia and Kazakhstan. Our company is relatively new and we don't have much experience in this business. But we hope, we will be able to represent your VIAR cameras in Russia and Kazakhstan.

9. 15 October, 2021

A - main paragraph;

$\mathrm{B}$ - salutation;

$\mathrm{C}$ - closing salutation;

D - sender's address;

E - receiver's address;

$\mathrm{F}$ - introductory paragraph;

$\mathrm{G}$ - date;

$\mathrm{H}$ - closing paragraph;

I - signature [4].

Эффективное формирование межкультурной компетенции магистрантов неязыкового вуза не возможно без активизации самостоятельной работы магистрантов. Основной упор мы делаем на самостоятельную работу магистрантов с культурологическим материалом. Несомненно, самостоятельная работа благотворно влияет на эффективность овладения языковым материалом, стимулируя познавательные и профессиональные интересы магистрантов, развивая их активность и инициативу, способствуя росту мотивации учения. Магистрантам предлагается выполнить задания подобного рода:

Task. Compose the letter below placing its parts in the proper order:

1. Diana Williams

Department of Interspace Communications

2. In our letter we would like to share some important information about our newly costructed device aimed to provide wireless communication between continents and even in space.

3. We would appreciate your prompt reply.

4. Created by Professors Derek Peters, Martin Gibson and Manufacturing Engineers Victor Jordan and Michael Davis, the device is currently undergoing field trials across the country.

5. Dear Mr. Grant,

6. If you think our work is worth being spoken about, we would like to ask you to give us a chance to present it. We would appreciate your attention to our research.

7. In the recent issue of Chemical Review we have found information on the scientific conference New Discoveries in Science to be held in Swansea. We are looking forward to reporting our new discovery and discussing it with the scientific public.

8. 22 November, 2021

9. Department of Interspace Communications

Southborough University

Pinal Way, Southborough 
Leicestershire LE98 3TU

Telephone: +44 (0)1509 223522

http://www.lboro.ac.uk/

10. Swansea University

Singleton Park

Swansea

SA2 8PP

Wales [5]

Следующее условие раскрывает важность наглядности, поскольку в изучении дисциплины «Деловой иностранный язык» магистрантам предлагается большое количество иллюстраций (образцы деловых писем, формы таможенных деклараций, резюме, примерные диалоги на заданные темы). Во время выполнения практических заданий магистранты активно используют предложенные образцы деловых писем и диалогов, выполняя подобные задания:

Задание. Прочитайте и переведите часть делового письма. Определите его вид. По образцу составьте свое собственное деловое письмо.

Dear Mr. Parkinson,

Mrs. Wrightbeard recommended that I contact you and ask for an interview.

I have recently graduated from Massachusetts University with a degree in Psychology. I am very interested in Psychology and would appreciate having the opportunity to discuss any vacancies that you can have in this specialty.

I am enclosing my resume for review and will look forward to meeting you.

Thank you for your consideration.

John Morrison

morjo@gmail.com

Tel: +7 912 XXXXXXXX [3].

Коллективный характер обучения и учет индивидуальных особенностей каждого магистранта, выявление мотивации каждого, учет их личных интересов и психологических характеристик является важным условием формирования коммуникационной компетенции магистрантов [6]. В рамках реализации данного условия каждый из магистрантов может выбрать любую интересную ему тему для написания делового письма (письмо-жалоба, письмо-запрос информации, резюме, письмо о приеме на работу и т.д.).

Дисциплина «Деловой иностранный язык» способствует формированию межкультурной компетенции магистрантов, поскольку с помощью изучения основ ведения деловой переписки на иностранном языке, постигая основы делового общения, магистранты, вместе с тем, знакомятся с нормами коммуникативного поведения в той или иной ситуации делового общения. Магистранты сталкиваются с межкультурным взаимодействием в деловой сфере при заказе и покупке билетов, при прохождении регистрации и таможенного контроля, при заселении в гостиницу и т.д. Также у магистрантов формируется готовность восприятия различных образцов коммуникативного поведения в деловой сфере. Они учатся понимать различия в деловом общении представителей англоязычного мира и их родной культуры. Наиболее важным нам представляется формирование межкультурной компетенции магистрантов через самообразование и готовность к получению знаний и навыков в сфере межкультурного взаимодействия в деловой сфере.

$* * *$

1. Иванов, И.И. Проблемы и перспективы инновационного развития РФ [Текст] / И.И.Иванов// Сборник статей Международной научно-практической конференции «Общество знаний: стратегии, процессы, технологии»» (Екатеринбург, 30.08.2017 г.). - Екатеринбург: Импульс, 2017. - 222 с.

2. Марковина, И.Ю. Формирование межкультурной компетенции как один из аспектов развивающего обучения: этнопсихолингвистический подход // Развивающее обучение в системе иноязычной подготовки: проблемы, инновации, перспективы. - М.: Рема, 2009 (Вестник Моск. гос. лингв. ун-та. Выпуск 567 Серия Педагогические науки). - С. 106-116. 
3. Николаева, Н.Т. Формирование коммуникативной компетенции магистрантов в рамках дисциплины "Деловой иностранный язык" (английский) / Н.Т. Николаева // Формирование личности будущего на основе психолого-педагогического анализа. Сборник статей Международной научно-практической конференции. 2017. C. $35-38$.

4. Николаева, Н.Т. Потенциал учебного предмета «Деловой иностранный язык» в формировании лингвокультуры магистрантов / Н.Т. Николаева // ОБЩЕСТВО ЗНАНИЙ: СТРАТЕГИИ, ПРОЦЕССЫ, ТЕХНОЛОГИИ сборник статей [Электронный ресурс] - М.: Импульс, 2018. - С 103-111.

5. Николаева, Н.Т. Педагогические условия и методическое сопровождение преподавания учебного предмета "Деловой иностранный язык" магистрантам с ограниченными возможностями здоровья / Н.Т. Николаева // Мир науки. Педагогика и психология. 2019. Т. 7. № 2. С. 23-32.

6. Свиридон, Р. А. Формирование межкультурной компетенции будущего специалиста в области мировой экономики средствами делового английского языка / Сборник научных трудов II Международной летней школы для молодых исследователей «Инновационные образовательные технологии в преподавании иностранных языков». - Томск. - Изд-во ТГПУ. - 2005 - С. $72-84$

\section{Норин Н.Е., Глушков П.Ю. \\ Методы и способы развития силовых качеств у военнослужащих войск национальной гвардии Российской Федерации}

Новосибирский военный институт имени генерала армии И.К. Яковлева войск нащиональной гвардии Российской Федеращии

(Россия, Новосибирск)

doi: 10.18411/trnio-11-2021-169

\section{Аннотация}

В статье рассматриваются методы развития физических качеств, способствующих подготовке военнослужащих, для успешного выполнения профессиональных задач служебно-боевой деятельности в современных условиях.

Ключевые слова: военнослужащие, физическая подготовка, аэробная нагрузка, анаэробная нагрузка, интервальная тренировка, методы развития.

\section{Abstract}

The article discusses methods of developing physical qualities that contribute to the training of military personnel for the successful performance of professional tasks of service and combat activities in modern conditions.

Keywords: military personnel, physical training, aerobic load, anaerobic load, interval training, development methods.

В апреле 2016 года Указом президента Российской Федерации В.В. Путина были образованы войска национальной гвардии, куда вошли основные силовые ведомства и внутренние войска. Изменения произошедшие в структуре силовых ведомств потребовали новых подходов к физической подготовке военнослужащих, т.к. задачи служебно-боевой деятельности претерпели значительные изменения. Управлением физической подготовкой войск национальной гвардии была С уверенностью можно сказать, что прошедшие три года проведена большая работа по разработке и внедрению в учебную деятельность Наставления по физической подготовке (НФП - 18), в котором определены основная цель и задачи по развитию физической подготовки на ближайшие десять лет. С уверенностью можно сказать, что прошедшие три года показали актуальность новых требований по развитию и совершенствованию физической подготовки. Введение ряда новых упражнений и изменений в методике проведения учебных занятий в настоящее время практически доказали, целесообразность новых подходов в обучении военнослужащих.

Однако есть необходимость более подробно остановиться на процессе формирования физических качеств у военнослужащих войск национальной гвардии, в связи с новыми знаниями в области физической культуры, которые рассматриваются современным 